\title{
EFEK LATIHAN PLIOMETRIK DAN LATIHAN LARI GAWANG PADA CEDERA LUTUT
}

Oleh : Ali Satya Graha

Dosen Jurusan Pendidikan Kesehatan dan Rekreasi FIK UNY

\section{Abstrak}

Program latihan dan metode latihan yang diberikan oleh seorang pelatih untuk peningkatan prestasi atlet, baik di even nasional maupun internasional tidak terlepas dari dukungan atlet itu sendiri, diantaranya: kondisi fisik yang sehat, komponen fisik yang baik dan bugar tanpa mengalami cedera.

Salah satu metode latihan yang popular digunakan oleh pelatih khususnya cabang lari gawang saat ini yaitu latihan pliometrik. Tetapi latihan pliometrik yang diberikan pada atlet lari gawang masih mengalami kendala seperti atlet mengalami cedera lutut yang terjadi setelah melakukan latihan pliometrik tersebut. Sedangkan saat melakukan latihan lari gawang kendala yang terjadi yaitu cedera pada lutut pula. Sehingga atlet melakukan dua kali aktivitas latihan, dengan mendapatkan cedera yang sama dan terus menerus. Cedera yang terjadi pada lutut atlet lari gawang akan timbul berbagai macam jenisnya, antaralain: tendinitis patellar, patella chondromalasia, bursitis anserinus pers, sindrom iliotibial band, knee sprain (keseleo lutut), cedera meniskal, tendinitis popliteal sindrom, plica lutut,

MEDIKORA Vol.III, No 2, Oktober 2007: 213-231 
pergeseran patella, malalignment makanisme ektensor dan cedera ligament krusiat anterior.

Penjelasan diatas perlunya penataan kembali pada pelaksanaan program latihan baik jangka pendek maupun panjang dan metode latihan yang aman bagi atlet atletik khususnya lari gawang supaya tidak mengalami cedera dan dapat meningkatkan prestasi atlet tersebut.

Kata kunci: Latihan pliometrik, Pelari Gawang, Cedera Lutut

Pengembangan prestasi puncak atlet, tidak terlepas dari peranan penerapan IPTEK olahraga dalam pembinaan prestasi agar menciptakan atlet yang berprestasi. Atlet berprestasi banyak terlahir dari keikutsertaan pelatih dalam memberikan program latihan dan metode latihan bagi atlet untuk mempersiapkan atletnya mengikuti event kejuaraan baik tingkat daerah, nasional maupun internasional seperti pada Pekan Olahraga Mahasiswa Nasional (POMNAS), Pekan Olahraga Nasional (PON), Universiade, ASEAN Games, Sea Games, Olimpiade (Media Olahraga, 2004). Salah satu metode latihan yang populer saat ini untuk melatih atlet khususnya atlet lari gawang pada cabang atletik yaitu menggunakan latihan pliometrik untuk meningkatkan kekuatan otot tungkai, kecepatan lari, dan daya ledak otot tungkai. Salah satu latihan pliometrik yang digunakan pada atlet lari gawang adalah teknik pliometrik. akan tetapi atlet yang telah 
melakukan teknik pilometrik selalu mendapatkan keluhan nyeri atau cedera pada tungkai.

Menurut Ferentinous (1999); Bompa (1999) serta Radcliffe (2003), bentuk latihan pliometrik seperti bound, jump dan hop, dilakukan dengan cara melompat ke atas depan dan mendarat dengan kaki yang sama. Mengamati pola gerak dari latihan pliometrik tersebut, pembeban pada tungkai yang menggunakan beban tubuh sendiri sewaktu melompat dan mendarat akan mudah menimbulkan cedera pada bagian lutut.

\section{METODE LATIHAN PLIOMETRIK}

Sejarah latihan pliomertik ini dimulai pada tahun 1960 oleh Yuri Veroskowski seorang pelatih atletik berasal dari Rusia. Istilah pliometrik atau plyometrics menurut Radcliffe (2003), berasal dari bahasa latin yang artinya peningkatan terukur. Definisi dari latihan pliometrik menurut Bompa (1999) dan Farentinous (1999), mengatakan bahwa latihan pliometrik adalah latihan yang mengarah kepada pengembangan daya ledak otot yang menimbulkan kontraksi otot eksentrik dan konsentrik. Pendapat para ahli di atas, diperjelas oleh hasil penelitian Moore dkk (2005), mengatakan bahwa latihan pliometrik yang diberikan pada seorang atlet

MEDIKORA Vol.III, No 2, Oktober 2007: 213-231 
secara kuantitatif dapat meningkatkan kekuatan vertikal lompatan, daya ledak otot tungkai, kemampuan melompat lebih tinggi dan merubah arah dengan cepat. Menurut Phill (2003), yang bahwa latihan pliometrik dapat meningkatkan kemampuan lompatan sewaktu melewati gawang. Pengertian para ahli diatas bahwa latihan pliometrik harus dilakukan oleh atlet dalam keadaan stamina prima dan bugar tanpa mengalami cedera saat melakukan latihan.

Menurut Radcliffe (2003), bahwa gerakan-gerakan pliometrik dilakukan dalam berbagai cabang olahraga yang menggunakan daya ledak otot anggota gerak atas dan bawah, seperti latihan pliometrik berupa latihan bound, jump, dan hop. Menurut Farentinous (1999); Bompa (1999) serta Radcliffe (2003), bentuk latihan pliometrik bound, jump dan hop dilakukan dengan cara berdiri dengan satu kaki, posisi badan setengah jongkok kemudian melompat ke atas depan dan mendarat dengan kaki yang sama. Seperti pada Gambar 1 di bawah ini:
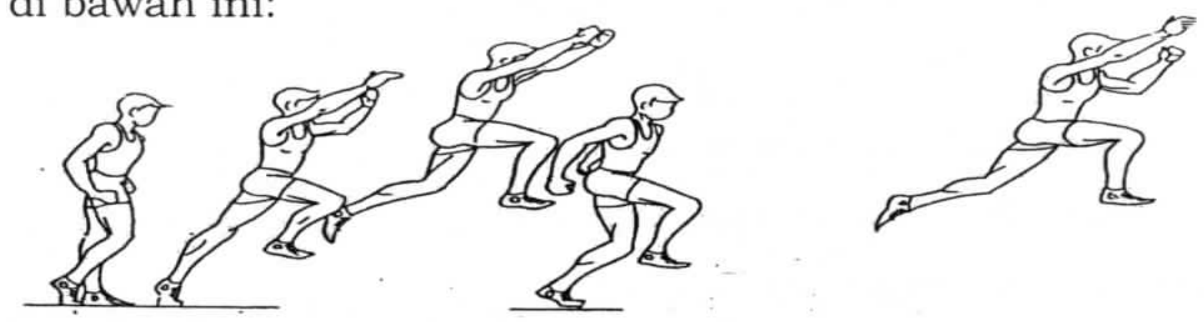

Gambar 1 : Bound, jump, dan hop (Bompa, 1999) 
Latihan pliometrik tidak boleh dilakukan oleh anakanak yang akan memasuki masa pubertas karena bisa menyebabkan kerusakan pada piringan epiphyseal yang belum menutup dengan sempurna (Ferentinous, 1999 dan Radcliffe, 2003). Menurut Bompa (1999), bahwa cedera yang sering dialami oleh para atlet yang melakukan latihan pliometrik yaitu pada persendian di bagian lutut. Hasil penelitian dari Escamilla (2000), menyebutkan bahwa jika seoarang atlet melakukan latihan pliometrik seperti bounding, hopping, atau jumping, dalam kondisi biomekanik yang salah maka akan menimbulkan cedera sendi lutut.

\section{CEDERA LUTUT PADA ATLET LARI GAWANG}

Lari gawang adalah seorang pelari berlari dengan secepat-cepatnya, dan ketika ada tempat tertentu yang dipasang gawang atau rintangan, dia akan melompat, lalu melanjutkan berlari sampai pada suatu tempat yang ada gawang berikutnya dan akan melompat lagi dengan tujuan akhir pada finis yang telah ditentukan (Subiyanto, 2007). Menurut Arnold (1997), bahwa dalam lari gawang ada hal yang tetap dan ada hal yang bervariasi. Hal yang tetap ditunjukkan dengan ukuran-ukuran seperti : jarak antara garis start ke gawang I $(13,72 \mathrm{~m})$, jarak antar gawang $(9,14 \mathrm{~m})$,

MEDI KORA Vol.III, No 2, Oktober 2007: 213-231 
jarak gawang akhir ke garis finis $(14,02 \mathrm{~m})$, tinggi gawang $(106,7 \mathrm{~m})$ dan sudut yang dilakukan pelari gawang sewaktu melintasi gawang adalah 45 derajat membentuk lengkungan parabola. Sedangkan yang bervariasi, seperti : kecepatan, kekuatan, power, kelentukan, perawakan atlet dan kebugaran atlet. Urutan teknik lari gawang seperti pada Gambar. 1 di bawah ini:

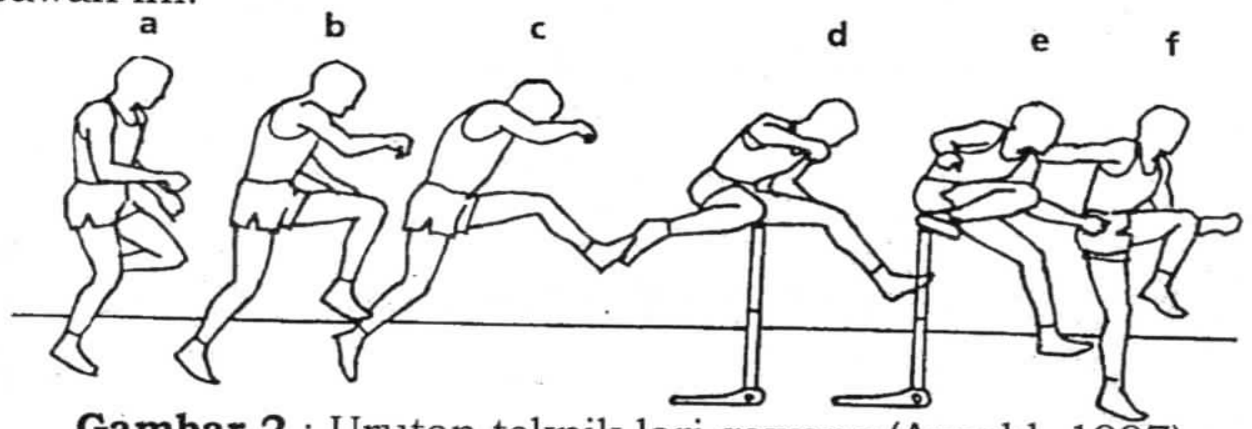

Gambar 2 : Urutan teknik lari gawang (Arnold, 1997)

Pengertian pelari gawang diatas, tidak hanya berlari melewati gawang dan menyelesaikan finis pada lintasan lari, tetapi pelari gawang memiliki predominan, yaitu: kecepatan untuk mendapatkan waktu tempuh yang baik. Akan tetapi pengertian diatas tidak akan tercapai apabila atlet lari gawang mengalami cedera lutut. Seperti yang diungkapkan oleh Arnold (1997), cedera pada cabang olahraga atletik khususnya atlet lari gawang, yaitu terjadi pada tungkai antara lain: cedera lutut. Banyak hal yang menyebabkan terjadinya cedera pada lutut. Seperti yang diungkapkan oleh 
Hardianto (1994), cedera olahraga khususnya pada cedera lutut terjadi disebabkan oleh: (1) metode latihan yang salah. (2) kelainan struktural yang menekan bagian tubuh tertentu lebih banyak daripada bagian tubuh lainnya seperti kelemahan pada otot, tendon dan ligamen. (3) Kebanyakan cedera ini disebabkan oleh penggunaan jangka panjang, dimana terjadi pergerakan berulang yang menekan jaringan yang peka.

Cedera lutut yang terjadi pada atlet banyak macamnya seperti tendinitis patellar, patella chondromalasia, bursitis anserinus pers, sindrom iliotibial band, knee sprain (keseleo lutut), cedera meniskal, tendinitis popliteal sindrom, plica lutut, pergeseran patella, malalignment makanisme ektensor dan cedera ligament krusiat anterior (taylor, 2002). Seperti yang diuraikan dibawah sebagai berikut:

\section{Cedera Tendinitis Patellar}

Tendon patellar adalah tendon yang menghubungkan patella atau mangkuk lutut dengan kaki bagian bawah atau tibia. Mangkuk ini sangat kuat dan menekan tendon dengan kuat, sehingga dikatakan sebagai lutut pelompat khususnya pada pelari gawang. Cedera tendinitis patellar merupkan sindrom yang terjadi karena adanya paksaan pada tendon saat melompat dan menumpu. Secara khusus atlet yang

MEDIKORA Vol.III, No 2, Oktober 2007: 213-231 
mengalami gejala ini akan merasakan nyeri setelah melakukan lompatan seperti pada cabang olahraga lari gawang, basket dan volly. Seperti pada Gambar. 2 dibawah ini:

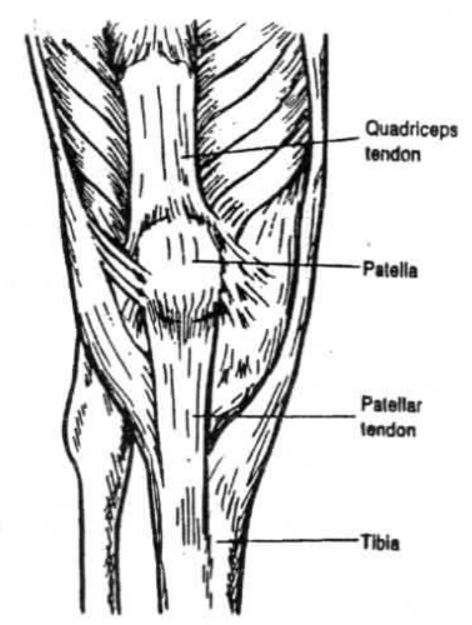

Gambar 3. Patellar tendon

\section{Cedera patella Chondromalasia}

patella chondromalasia atau sering disebut lutut pelari. Cedera patella chondromalasia yaitu sindrom yang disebabkan karena adanya tekanan terjadi secara berulangulang pada lutut sehingga menyebabkan terjadinya peradangan pada jaringan kartilago dibawah patella. Hal ini akan menyebabkan pergeseran pada patella dan tulang femur yang mengakibatkan rasa nyeri dan pembengkakan pada lutut. Penyebabnya cedera patella chondromalasia adalah 
lemahnya otot paha, ketidak seimbangan otot, cedera ligament yang dibiarkan dan tidak terawat.

\section{Bursitis Anserinus Pers}

Bursa merupakan suatu tempat yang berisi cairan yang berada diantara dua struktur tulang yang bersentuhan satu sama lain. Cairan ini berupa minyak yang hampir sama dengan cairan persendian tetapi jumlahnya sedikit. Bursitis yaitu peradangan pada bursa yang dapat disebabkan oleh adanya friksi, benturan secara langsung pada persendian, atau disebabkan oleh infeksi bakteri. Gejala sindrom ini yaitu rasa sakit atau rasa perih lokal pada atas permukaan tibia dan rasa sakit timbul karena adanya gerakan-gerakan dari lutut. Bursitis ini terjadi pada atlet lari jarak dekat dengan melatih meningkatan kecepatan lari yang berlebihan..

\section{Sindrom Iliotibial Band}

sindrom iliotibial band terjadi akibat kombinasi antara keabnormalan anatomis dengan latihan yang tidak benar dan baik pada atlet. Iliotibial merupakan otot yang sangat berperan dalam otot menyeimbangkan lutut, menggerakan lutut kedalam dan mengembangkan lutut saat berlari. Apabila terjadi kekencangan otot ilitibial saat lutut bergerak fleksi dan ekstensi secara berulang-ulang selama berlari maka bursa tersebut akan mengalami peradangan dan cedera

MEDIKORA Vol.III, No 2, Oktober 2007: 213-231 
pada sendi lutut bagian luar. Gejala sindrom ini yaitu rasa sakit pada ilitibia dan lutut. Seperti terlihat pada gambar dibawah ini:

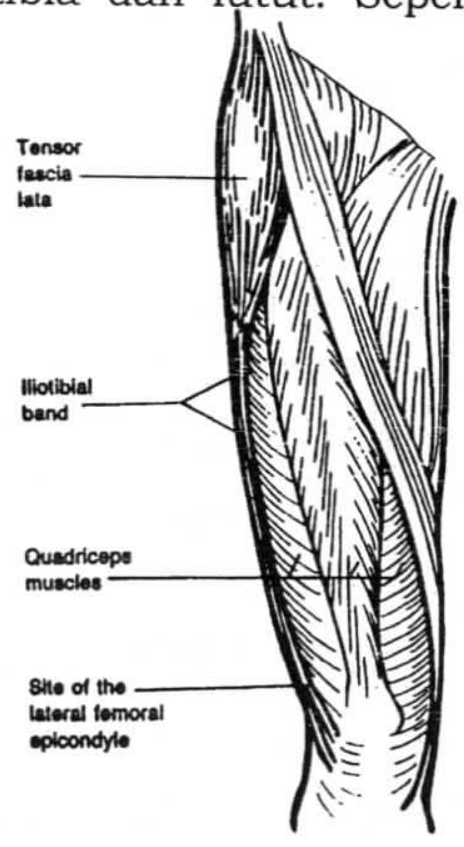

Gambar 4. iliotibial band

\section{Knee Sprain (keseleo lutut)}

Keseleo lutut merupakan cedera pada ligamen yang disebabkan oleh adanya tekanan pada tensil. Cedera keseleo ini terjadi pada pelari akibat salah berlari atau salah menupu saat berlari atau melompat pada lari gawang. Ada tiga tingkatan cedera keseleo, yaitu:

(1) keseleo ringan dimana tingkatan keseleo ini, lutut hanya mengalami kerusakan pada otot ligamennya. 
Gejala yang timbul yaitu rasa sakit, pembengkakan kecil, sedikit pendarahan tetapi tidak terjadi perobekan yang besar. Keseleoringan ini cukup dirawat dengan pemberian kompres es.

(2) Keseleo sedang, dimana terjadi kerusakan ligamen yang lebih besar tetapi tidak sampai ligamen terputus total. Gejala yang timbul rasa sakit, bengkak, terjadi pendarahan yang hebat dan ketidak stabilan pada lutut.

(3) Keseleo berat, dimana terjadi kerusakan ligamen yang lebih besar terputus total. Gejala yang timbul rasa sakit, bengkak, terjadi pendarahan yang hebat dan lutut tidak bisa digerakan. Perawatan dengan istirahat total dan operasi pada ligamen yang terputus tadi..

\section{Cedera Meniskal}

Kartilago lutut seringkali disebut juga meniscus, seringkali mengalami cedera. Kartilago yang bentuknya khusus ini berbeda dengan kartilago lainnya, bakdalam fungsi maupun strukturnya. Kartilago secara umum biasanya berupa jaringa yang sangat halus yang memungkinkan lutut dapat bergerak dengan bebas. Kartilago ini berbentuk seperti sebuah kelereng dan sifatnya seperti plastik. Kartilago meniskal sebaliknya, berbentuk seperti huruf ' $C$ ' yang terletak

MEDI KORA Vol.III, No 2, Oktober 2007: 213-231 
antara kartilago artikular femur da tibia di dalam lutut. Ada dua jenis meniskus kartilago pada masing-masing kutut. Yang membentuk cekungan dangkal, berfungsi sebagai stabilisator. Seperti pada Gambar 4 dibawah ini:

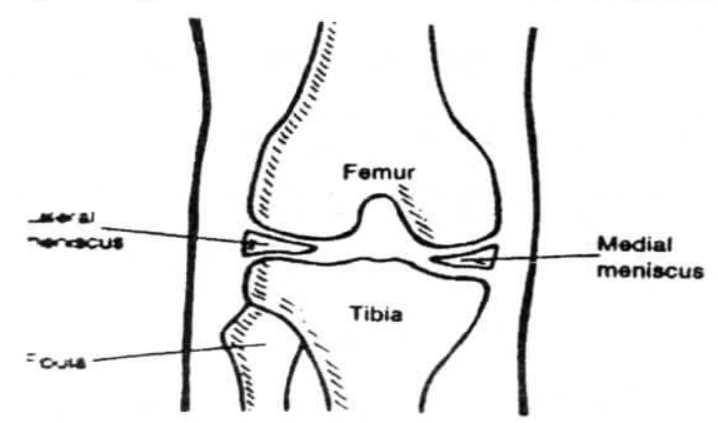

Gambar 5. Meniski sebagai bantalan femur dan tibia

Bentuk cedera pada kartilago biasanya sebagai akibat adanya penekukan secara tiba-tiba dan cedera akibat terjadinya penekanan pada lutut. Biasanya banyak terjadi pada pelari gawang yang terbiasa mengarahkan kakinya hanya pada satu arah dan dilakukan secara tiba-tiba sehingga mengalami tekanan pembelokan pada lutut atau saat salah melangkahkan kaki.

\section{Tendinitis Popliteal}

Tendinitis popliteal disebabkan oleh adanya rasa sakit pada lutut bagian samping (lateral). Sering dialami oleh atlet lari maupun atlet olahraga lainnya. Kebanyakan para atlet telah mengetahui cedera chondromalasia (lutut pelari) dan 
beberapa masalah cedera yang berhubungan dengan mangkuk lutut, namun perlu dijelaskan disini bahwa tidak semua kąsus cedera lutut berhubungan dengan patella. Rasa sakit pada bagian samping lutut atau bagian luar sisi lutut mungkin berasal dari kondisi yang berbeda, termasuk juga pada tendinitis popliteal. Seperti pada Gambar 5 dibawah ini:

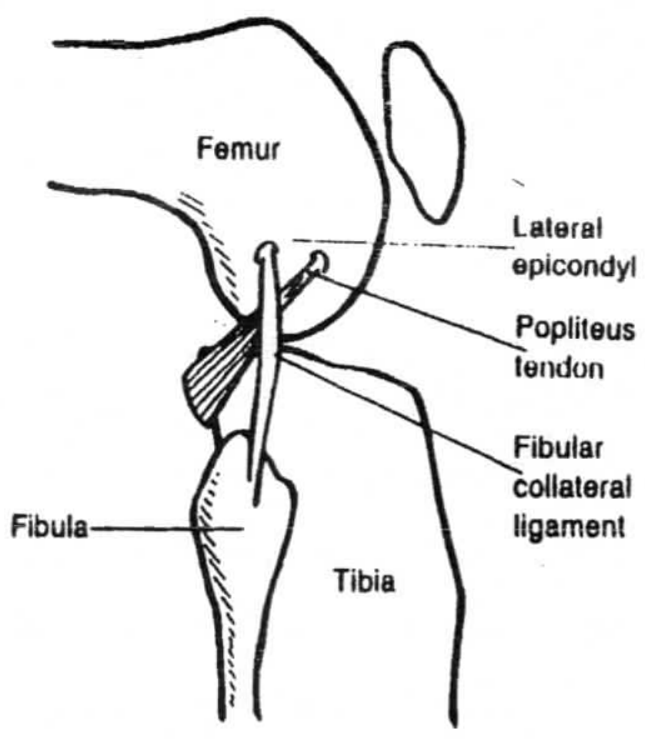

Gambar 6. Tendon Popliteus

\section{Sindrom Plica Lutut}

Sindrom plica disebabkan oleh adanya penebalan pada lapisan persendian lutut. Biasanya terjadi pada bagian dalam tepat pada perbatasan patella (mangkuk lutut) bagian atas. Lapisan-lapisan persendin tersebut tersusun dari jaringan

MEDI KORA Vol.III, No 2, Oktober 2007: 213-231 
yang dinamakan synovium. Jaringan synovium ini memproduksi cairan pelumas yang disebut synovial. Jika terjadi penebalan pada lapisan ini, maka lapisan akan menggesek pada bagian-bagian lutut lainnya, khususnya bagian dalam femural condyle (ujung bagian bawah dari tulang paha) sehingga menimbulkan rasa sakit dan iritasi.

\section{Pergeseran Patella}

Patella, atau tempurung lutut berfungsi sebagai tempat penunjang (fulcrum) otot-otot quadriceps maupun otot-otot paha, untk memproleh manfaat mekanik sehingga menimbulkan tenaga atau kekuatan untuk menggerakkan kaki (otot-otot quadriceps merupakan otot utama yang berperan dalam stabilitas kaki). Jelasnya, tempurung lutut ini penting sekali dalam setiap aktifitas olahraga terutama yang menbutuhkan gerakan pada kaki bawah. Patella merupakan lapisan piringan sendi tulang ang terletak pada ujung femur. Femur ini memiliki celah pada ujungnya, yang merupakan tempat patella pada saat kaki melakukan gerakan menekuk (gambar). Jika patalla keluar dari celahnya dan berpindah ke salah satu sisi akan menimbulkan pergeseran letak. Pergeseran yang tidak pada tempatnya ini merupakan subluksi, di mana tempurung lutut tidak menempati posisi sebagaimana mestinya tetapi menyelip sedikit ke salah satu 
sisi, ini akan menimbulkan rasa sakit dan dapat diperkirakan telah terjadi pergesaran tempat patella.

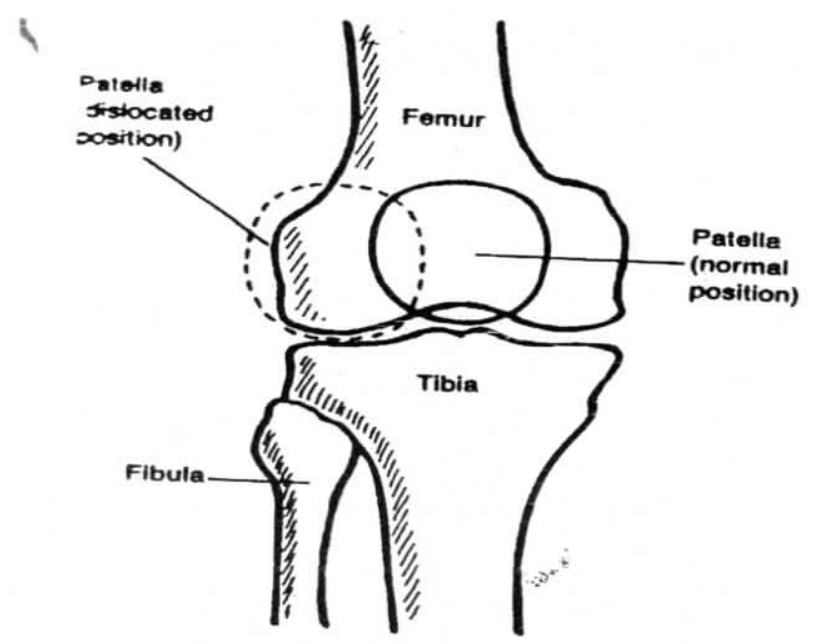

Gambar 7. Pergeseran Patella

\section{Malalignment Mekanisme Ekstensor (sindrom malalignment malicious)}

Sindrom malalignment malicious adalah suatu kombinasi dari adanya ketidakseimbangan biomekanis pada kaki bawah yang cenderung menimbulkan cedera. Oleh beberapa pengarang seringkali disebut sebagai malicious malalignment syndrome, miserable malaligment syndrome, atau extensor mechanism malalignment. Sindrom ini meliputi perputaran internal pinggul, posisi tempurung lutut mengarah ke dalam (squinting patella),

MEDI KORA Vol.III, No 2, Oktober 2007: 213-231 
posisi kaki pengkar keluar dan kadang-kadang penekuka kaki bawah (tibia), telapak kaki yang mendatar (melakukan pronaşi yang berlebihan).

Gambar 8. Pengukuran $Q$ pada penderita cedera ekstensor malalignment

\section{Cedera Ligamen Krusiat Anterior}

Anterior cruciate ligament berada di dalam lutut da berperan sekali dalam mendukung prestasi terutama pada olahraga yang membutuhkan perubahan gerakan pada gerakan secara tiba-tiba dan perubahan kecepatan. Seperti pada lari gawang. Ligamen menyatukan tulang-tulang secara bersamaan. Anterior crusiate ligament merupakan sekelompok jaringan keras, memiliki diameter kira-kira sebesar lingkaran jari. Jaringan ini tidak dapat kita rasa dan kita lihat, terletak pada 
bagian dalam lutut antara persendian femur dan tibia. Menurut definisi tersebut, ligamen ini menyilang pada bagian depan internal ligamen lutut (juga terdapat sebuah posterior cruciate ligament, yang berfungsi menyeimbangkan anterior cruciate ligament, ligamen ini juga sangat penting. Dapat dilihat pada Gambar 8 dibawah ini:.

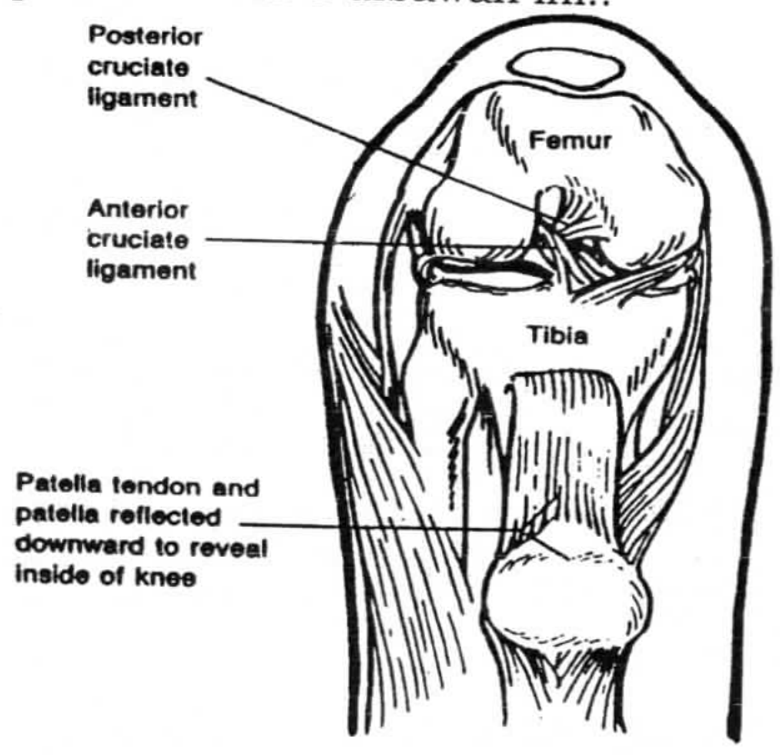

Gambar 9. Ligament Krusiat Anterior

Pada macam-macam cedera lutut yang dijelaskan diatas sering terjadi pada latihan pliometrik dan lari gawang dalam pemberian latihan untuk meningkatkan prestasi atlet. Sehingga atlet sebelum bertanding atau sedang bertanding tidak dapat maksimal melakukan keinginan pelatih atau keinginan atlet tersebut dalam meningkatkan prestasinya.

MEDIKORA Vol.III, No 2, Oktober 2007: 213-231 


\section{KESIMPULAN}

Dari Uraian diatas dapat disimpulkan sebagaio berikut:

1. Latihan pliometik yang tidak terukur dalam pemberian latihannya akan menyebabkan atlet mengalami cedera pada lutut.

2. Cabang olahraga atletik khususnya lari gawang sangat rawan bagi atlet lari gawang terhadap resiko cedera pada lutut karena bisa timbul akibat lari dan melompat dengan kecepatan tinggi dan power yang besar untuk melewati gawang-gawang pada lintasan atletik.

3. Cedera lutut yang timbul akibat melakukan latihan pliometrik dan lari gawang banyak macamnya, antaralain: tendinitis patellar, patella chondromalasia, bursitis anserinus pers, sindrom iliotibial band, knee sprain (keseleo lutut), cedera meniskal, tendinitis popliteal sindrom, plica lutut, pergeseran patella, malalignment makanisme ektensor dan cedera ligament krusiat anterior.

\section{Daftar Pustaka}

Arnold, 1997, Lari Gawang (Hurdling), PB PASI, Indonesia

Bompa, Tudor O., 1999, Power Training for Sport (Canada: Mosaic Press) 
Departemen Kementrian Olahraga, 2004, Media Olahraga, Jakarta.

Escamila, Rafael F, dkk, 2000, A Three Dimensional Biomechanical Analysis of Squat During Varying Stance Widths, Medicine \& science in Sports \& exercise, USA

Farentinos,R.C, 1999, Plyometric (Champaign: Human
Kinetics Publisher),

Hardianto. W. (1994), Pencegahan dan penatalaksanaan Cedera Olahraga, EGC Penerbit Buku Kedokteran. Jaakarta.

Radcliffe, J, 2003, Form and Safety in Plyometric Training, NCSA Performeance Training Journal. Vol 2. Number 2,

Moore, Christopher A., and Schilling, Brian K., 2005, Theory and Application of Augmented Eccentric Loading. National Strength and Conditioning Journal, 27(5), 20-

Phill Lundin, 2003, Plyometric Training Loads for Youths and Beginners, University of Minnesota, USA, Journal of Strength and Conditioning research, Pages 3211-3214.

Subiyanto, 2007, Peningkatan Prestasi Lari Gawang, Seminar To Be A Winner, Karang Pandan, Karang Anyar, Jawa Tengah.

Taylor M. Paul, 2002, Mencegah dan Mengatasi Cedera Olahraga, PT Raja persada, Jakarta.

MEDI KORA Vol.III, No 2, Oktober 2007: 213-231 